\title{
Bamboo Bonding in Concrete: A Critical Research
}

\author{
Abhishek Dixit, Vishal Puri
}

\begin{abstract}
Housing needs across developing countries are at its peak especially due to increasing population growth rate. This has caused a great demand for conventional building materials leading to over-exploitation of natural resources required for their production along with their detrimental effects on the environment. Sustainable construction practices are thus required which involves the application of materials such as bamboo, fly ash, kenaf, etc. Bamboo is a lightweight, costeffective, environment-friendly material with more than six times the strength by weight ratio compared to steel. This paper reviews the application of bamboo in the form of reinforcement in concrete with detailed aspects focussed on its bond strength development in concrete. Different bamboo reinforcement treatment processes developed in literature combined with their applications and limitations are presented. It was observed that with Sikadur 32 Gel epoxy coating method and with the application of G.I. rolled wires method, 3.25MPa and 9.71MPa of bond strength could be achieved respectively. This highlights that with proper surface treatment processes, bamboo as reinforcement in concrete can develop significant bond strength compared to steel reinforcement. However, issues such as lack of codal guidelines, non-standardized pull out testing mechanism to incorporate density variation of fibers, combined with wide variation in its properties requires further standardization before its mass application.
\end{abstract}

Keywords: Bamboo, Bamboo Bonding, Bamboo Reinforced Concrete, Low-Cost Housing, Sustainable Material.

\section{INTRODUCTION}

In developing countries like India, the migration of people from village areas to urban cities are causing a huge housing shortage in cities. Currently, the shortage of more than 10 million houses is reported in Indian urban cities (Report on 'Affordable housing in India'). The population growth rate of India in 2019 is reported as 1.08\% which is higher than the world population growth rate of $1.07 \%$ as reported by Department of Economics and Social Affairs, Population Division (Accessed on www.worldometers.info). Such a huge population growth rate causes tremendous demand for housing leading to the exploitation of conventional natural resources such as iron ore required for producing steel reinforcement. Further, the production of these conventional production of a large amount of greenhouse gases.

Steel production causes an environmental impact by emitting gases such as $\mathrm{CO}, \mathrm{SO}_{\mathrm{X}}, \mathrm{NO}_{\mathrm{X}}$, and $\mathrm{PM}_{2}$, primarily being the carbon dioxide gas. Apart from these it also

Revised Manuscript Received on September 10, 2019.

Abhishek Dixit, M.Tech Structural Engineering, Amity University, Noida, Uttarpradesh, India.

(Email: dixitabhishek2512@gmail.com)

Dr. Vishal Puri, Assistant Professor, Department of Civil Engineering, Amity University, Noida, Uttarpradesh, India.

(Email: vpuri@amity.edu) materials is also detrimental to the environment due to the

produces wastewater contaminants, hazardous wastes and solid wastes which poses a threat to the environment. Further with increased demand, the steel costs have risen significantly over the years. This hinders its application for low-cost housing. Similarly, cement production results in high levels of carbon-dioxide emissions. As per the recent report (National Cement Consumption, CAGR 2017-2021), the cement production growth has been reported to be more than 5\% in many developing countries across the globe (Figure 1) leading to the huge production of greenhouse gases. Cement production alone contributes $4-5 \%$ of the total worldwide emission of carbon-dioxide. Similarly, for steel, the demand was observed to be about 1648 million tonnes (Accessed on worldsteel.org) across the globe (Figure 2). Also, the extraction of raw materials causes the degradation of land, loss of agricultural land, dust and noise pollution. In addition to this, the transportation of these raw materials results in vehicle pollution, noise pollution and excessive consumption of fuel further deteriorating the environment

Thus, there is a requirement for alternative sustainable materials such as bamboo, jute, kenaf, fly ash, rice husk, straw bales, recycled aggregates, palm oil shell, etc. Considerable research is focussed on such unconventional building materials which are cost effective and are sustainable.

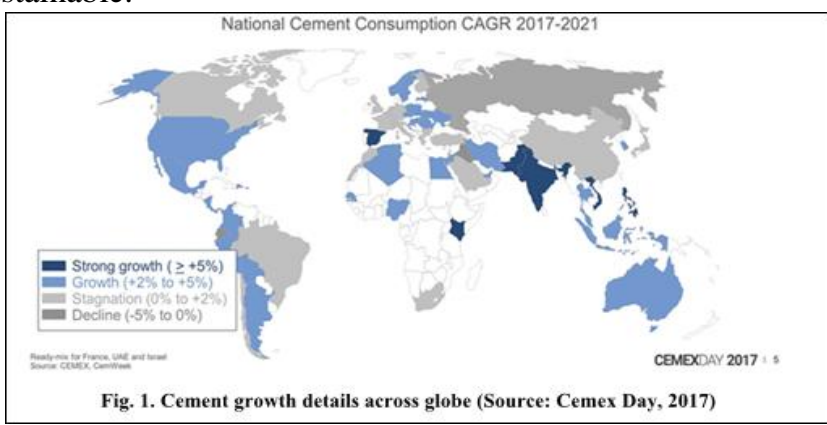

Bamboo is one such sustainable building material which has higher than six times the strength by weight ratio comparable with steel (Ghavami, 2005). The amount of $\mathrm{CO}_{2}$ emission in the atmosphere in case of bamboo is 50 times less as compared to steel and cement. Further, bamboo also consumes around 1 tonne of carbon dioxide during its growth phase (Xiao et al., 2013; Sharma et al., 2014). However, there are different issues such as properties variation across species, bond strength development in concrete, treatment processes involved in the application of bamboo in the form of reinforcement in concrete. This study 
evaluates bamboo bond issues in concrete and discusses the different shortcomings which require further research.

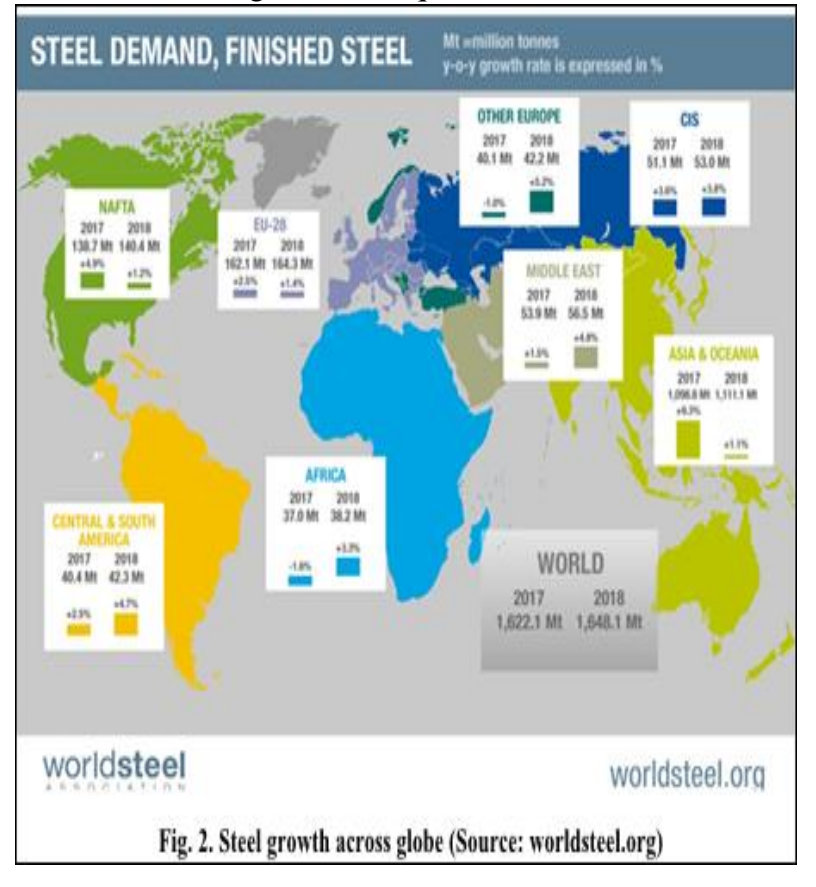

\section{BAMBOO AS REINFORCEMENT IN CONCRETE}

Bamboo, which is a form of natural grass, has more than 1200 species found across the globe which can serve the purpose of replacing steel in concrete due to its various advantages (Sharma et al., 2014). The distribution of bamboo across the globe (Schroder, 2016) is shown in Figure 3. Most of the species are found across many developing countries where their application potential is immense

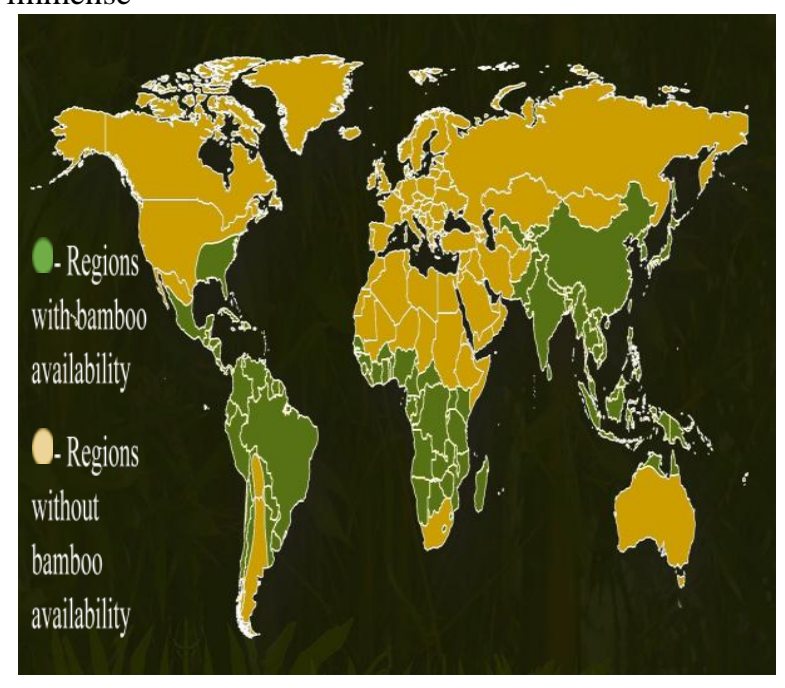

Fig, 3. Distribution of Native Bamboo around the world. (Source:

https://www.bambooimport.com/en/blogg/facts-about-bamboo)

Different advantages of bamboo comparable to mild steel include high tensile strength (Ghavami, 1995), the fast growth rate of up to $91 \mathrm{~cm}$ per day (Guinness world record), low cost, less weight, and energy efficiency (Ghavami, 1995; Ghavami, 2005). Bamboo has been used as a building material in village areas from decades. Most of the northeastern states of India still have the majority of dwellings based on bamboo reinforcement highlighting its great potential.

Numerous research studies across the world have started to recognize this potential by evaluating the performance of bamboo reinforcement in different structural components. Table 1 discusses the research application of bamboo reinforcement as evaluated in different studies. 
Table 1. Bamboo as reinforcement in different structural components.

\begin{tabular}{|c|c|c|}
\hline Researcher/ Year & Research area & Outcome/Findings \\
\hline H. K. Chow (1914) & $\begin{array}{l}\text { Bamboo used in the form } \\
\text { reinforcing material in } \\
\text { concrete beams. }\end{array}$ & $\begin{array}{l}\text { Tested small diameter bamboo and bamboo splits } \\
\text { in the form of reinforcing material for concrete } \\
\text { applications which showed positive results. }\end{array}$ \\
\hline K. Datta (1936) & $\begin{array}{l}\text { Experiments on the use of } \\
\text { bamboo in concrete } \\
\text { construction. }\end{array}$ & $\begin{array}{l}\text { Studied the future possibility of bamboo in } \\
\text { various applications due to its outstanding } \\
\text { mechanical and technical properties. }\end{array}$ \\
\hline H. E. Glenn (1950) & $\begin{array}{l}\text { Bamboo in the form of } \\
\text { reinforcement material in } \\
\text { full-scale building. }\end{array}$ & $\begin{array}{l}\text { Tested small diameter bamboo and bamboo } \\
\text { splints application by using it in the full-scale } \\
\text { building. Observed that the results were feasible } \\
\text { in principle but due to various disadvantages } \\
\text { related to bamboo, de-bonding occurred between } \\
\text { bamboo and concrete and the building collapsed } \\
\text { after a few days. }\end{array}$ \\
\hline McClure (1953) & $\begin{array}{l}\text { Use of untreated unseasoned } \\
\text { bamboo in the form of } \\
\text { reinforcement in longitudinal } \\
\text { direction embedded in } \\
\text { concrete. }\end{array}$ & $\begin{array}{l}\text { Reported that cracks in longitudinal direction in } \\
\text { concrete were due to the absorption of water in } \\
\text { bamboo. It also reduces the load bearing capacity } \\
\text { of the concrete members. It has also been } \\
\text { observed that when the treatment of brush coat } \\
\text { of asphalt emulsion is done, it showed better load } \\
\text { carrying capacity. }\end{array}$ \\
\hline $\begin{array}{l}\text { F.E. Brink and P.J. Rush } \\
\text { (1966) }\end{array}$ & $\begin{array}{l}\text { Guidelines related to } \\
\text { construction using concrete } \\
\text { which is reinforced with } \\
\text { bamboo were developed. }\end{array}$ & $\begin{array}{l}\text { List of guidelines about the utilization of bamboo } \\
\text { in construction was developed. They concluded } \\
\text { that bamboo which is green and unseasoned } \\
\text { should be avoided for construction. The bamboo } \\
\text { which is at least } 3 \text { years in age and is brown in } \\
\text { colour after waterproofing should be used. It has } \\
\text { been observed that mix design can be the same } \\
\text { for bamboo and steel but the slump can go to the } \\
\text { point at which the workability condition is } \\
\text { satisfied. }\end{array}$ \\
\hline $\begin{array}{l}\text { H.G. Geymayer and F.B. } \\
\text { Cox (1970) }\end{array}$ & $\begin{array}{l}\text { Studied the use of bamboo } \\
\text { reinforcement for temporary } \\
\text { structures. }\end{array}$ & $\begin{array}{l}\text { Determined that bamboo has a tensile strength as } \\
\text { high as } 37 \mathrm{Mpa} \text { but the Young's Modulus of } \\
\text { bamboo is as low as one-tenth of steel. Also } \\
\text { observed that the ultimate flexural load bearing } \\
\text { capacity of bamboo reinforced members is } 2 \text { to } 4 \\
\text { times higher than unreinforced members of same } \\
\text { dimensions. It also says that the use of bamboo } \\
\text { splints is more advantageous than using bamboo } \\
\text { culms as a whole in reinforcement. }\end{array}$ \\
\hline $\begin{array}{l}\text { M.A. Mansur and M.A. } \\
\text { Aziz (1983) }\end{array}$ & $\begin{array}{l}\text { Performed some tests by } \\
\text { using woven mesh made from } \\
\text { bamboo slints on cement } \\
\text { composites. }\end{array}$ & $\begin{array}{l}\text { The study revealed that the use of bamboo in the } \\
\text { form of mesh enhances the toughness and ductile } \\
\text { nature of the mortar and also improves its tensile, } \\
\text { flexural and impact strength. }\end{array}$ \\
\hline $\begin{array}{l}\text { J.A. Kankam, M. B. } \\
\text { George and S.H. Perry } \\
\text { (1986) }\end{array}$ & $\begin{array}{l}\text { Studied the effect of using } \\
\text { bamboo reinforcement on a } \\
\text { two-way concrete slab. }\end{array}$ & $\begin{array}{l}\text { Reported that the seasoned bamboo has a high } \\
\text { tensile strength than unseasoned bamboo. Also } \\
\text { observed that more than } 4 \% \text { reinforcement of } \\
\text { bamboo should not be used in concrete } \\
\text { structures. Also suggested that further studies are } \\
\text { required to find out the long term characteristics } \\
\text { of bamboo in terms of humidity along with the } \\
\text { chemical reactions between bamboo and } \\
\text { concrete. }\end{array}$ \\
\hline
\end{tabular}




\begin{tabular}{|c|c|c|}
\hline $\begin{array}{l}\text { J.A. Kankam, M. B. } \\
\text { George and S.H. Perry } \\
(1988)\end{array}$ & $\begin{array}{l}\text { Studied about the bamboo } \\
\text { reinforced concrete beams } \\
\text { subjected to third-point } \\
\text { loading. }\end{array}$ & $\begin{array}{l}\text { Suggested few measures on improving the bond } \\
\text { strength between bamboo and concrete like } \\
\text { seasoning, filing of smooth surfaces and } \\
\text { waterproof paint coating with sand treatment. }\end{array}$ \\
\hline K. Ghavami (1995) & $\begin{array}{l}\text { Studied the mechanical } \\
\text { properties of bamboo used in } \\
\text { simply supported lightweight } \\
\text { concrete beams. }\end{array}$ & $\begin{array}{l}\text { Observed that the ultimate load carrying } \\
\text { capacity of bamboo reinforced concrete beam is } \\
400 \% \text { of the un-reinforced concrete beam. The } \\
\text { modulus of elasticity for bamboo is } 1 / 15 \text { of steel } \\
\text { and the tensile strength of bamboo was much } \\
\text { higher than its compressive strength. }\end{array}$ \\
\hline J. Janssen (2000) & $\begin{array}{l}\text { Studied the building } \\
\text { constructed with bamboo and } \\
\text { also presented the details on } \\
\text { joints. }\end{array}$ & $\begin{array}{l}\text { The study highlighted the limitations while using } \\
\text { bamboo in the building made with bamboo } \\
\text { reinforced concrete. The limitations observed } \\
\text { were bond strength, absorption of water in the } \\
\text { bamboo, smooth wall of the bamboo culm. Out of } \\
\text { all the limitations, improper bond strength was } \\
\text { found out to be the biggest issue. }\end{array}$ \\
\hline $\begin{array}{l}\text { S. Amada and S. Untao } \\
\text { (2001) }\end{array}$ & $\begin{array}{l}\text { Studied the fracture } \\
\text { properties of bamboo. }\end{array}$ & $\begin{array}{l}\text { Observed that the tensile strength of bamboo } \\
\text { fibers was comparable to steel. Further, the } \\
\text { origin of fracture is the main reason on which the } \\
\text { fracture properties of bamboo depends. Also, the } \\
\text { fibers in the nodes of bamboo do not have any } \\
\text { role in fracture resistance. }\end{array}$ \\
\hline S. Iyer (2002) & $\begin{array}{l}\text { Studied the applications of } \\
\text { bamboo reinforcement and } \\
\text { provided some guidelines. }\end{array}$ & $\begin{array}{l}\text { Some guidelines were set for constructing } \\
\text { seismically safe reinforced masonry dwellings. It } \\
\text { was concluded that bamboo can be used } \\
\text { effectively in place of steel as reinforcement in } \\
\text { cement concrete and can be cost-effective in } \\
\text { bearing masonry for seismically safe houses. }\end{array}$ \\
\hline $\begin{array}{l}\text { W. Yao and Z. Li } \\
(2003)\end{array}$ & $\begin{array}{l}\text { Studied the behaviour of } \\
\text { bamboo reinforced mortar } \\
\text { laminates under flexure. }\end{array}$ & $\begin{array}{l}\text { In this study extruded fiber reinforced mortar } \\
\text { sheet and sandwich plate which is combined with } \\
\text { reformed bamboo plate were considered. } \\
\text { Observed that the reformed bamboo can enhance } \\
\text { and improves the strength of mortar along with } \\
\text { reducing the total weight of laminate due to the } \\
\text { high strength by weight ratio. }\end{array}$ \\
\hline K. Ghavami (2005) & $\begin{array}{l}\text { Studied the structural } \\
\text { properties of bamboo and } \\
\text { also the various kinds of } \\
\text { treatments for bamboo which } \\
\text { can be used as reinforcement. }\end{array}$ & $\begin{array}{l}\text { Observed that the bamboo in the direction } \\
\text { parallel to fibers showed high strength and is } \\
\text { termed as a functionally graded composite. Also } \\
\text { concluded that the use of } 4 \% \text { bamboo as a } \\
\text { reinforcement in the concrete beam is ideal for } \\
\text { maximum efficiency. Apart from these columns } \\
\text { and floor slabs reinforced with bamboo were also } \\
\text { tested which showed that bamboo can be an } \\
\text { effective cheap substitute for steel. }\end{array}$ \\
\hline L. Khare (2005) & $\begin{array}{l}\text { Studied the use of bamboo } \\
\text { reinforcement in concrete } \\
\text { beams. }\end{array}$ & $\begin{array}{l}\text { Reported that there is an increment in the load } \\
\text { carrying capacity by } 250 \% \text { after the use of } \\
\text { bamboo as reinforcement as compared to initial } \\
\text { crack load on the concrete beam. Also, observed } \\
\text { that beams reinforced with bamboo have an } \\
\text { average of } 35 \% \text { load carrying capacity in } \\
\text { comparison to beams reinforced with steel. }\end{array}$ \\
\hline $\begin{array}{l}\text { M. Terai and K. Minami } \\
\text { (2011) }\end{array}$ & $\begin{array}{l}\text { Studied the effect of using } \\
\text { bamboo as a reinforcement in } \\
\text { beams and columns. }\end{array}$ & $\begin{array}{l}\text { Observed that beam reinforced with bamboo } \\
\text { shows a similar pattern of cracking to that of } \\
\text { normal reinforced beams. The already available } \\
\text { formula of fracture behavior for reinforced } \\
\text { concrete beams can be used for bamboo } \\
\text { reinforced beams. }\end{array}$ \\
\hline
\end{tabular}




\begin{tabular}{|c|c|c|}
\hline $\begin{array}{l}\text { A. Agarwal, B. Nanda and } \\
\text { D. Maity (2014) }\end{array}$ & $\begin{array}{l}\text { Studied the use of bamboo } \\
\text { reinforcement in beams and } \\
\text { columns and compare it with } \\
\text { unreinforced members. }\end{array}$ & $\begin{array}{l}\text { The treatment on the bamboo surface is done } \\
\text { with the use of some chemicals. When a member } \\
\text { is subjected to axial loading the bamboo gives } \\
\text { sufficient ductility so that there is a warning } \\
\text { before the failure of members. It was observed } \\
\text { that the columns which are reinforced with } 8 \% \\
\text { treated bamboo gives the same strength and } \\
\text { behavior under transverse and axial loading as } \\
\text { that of normal RCC columns. }\end{array}$ \\
\hline $\begin{array}{l}\text { A. Javadian, M. } \\
\text { Wielopolski, F.C. Smith } \\
\text { and D.E. Hebel (2016) }\end{array}$ & $\begin{array}{l}\text { Used various chemical } \\
\text { treatments on bamboo and } \\
\text { calculated the bond strength. }\end{array}$ & $\begin{array}{l}\text { In this study, the bonding properties of newly } \\
\text { developed bamboo composite reinforcement were } \\
\text { evaluated. Different chemical treatments were } \\
\text { made on bamboo composite reinforcement. It was } \\
\text { observed that the bamboo composite } \\
\text { reinforcement without any coating showed } \\
\text { adequate bond strength. However, when epoxy } \\
\text { based coating with fine sand particles was used, } \\
\text { the bond strength increased to 3.65MPa. }\end{array}$ \\
\hline $\begin{array}{l}\text { V. Puri, P. Chakrabortty, } \\
\text { S. Anand and S. } \\
\text { Majumdar (2017) }\end{array}$ & $\begin{array}{l}\text { Prepared wall panel which } \\
\text { was prefabricated and the } \\
\text { bamboo mesh was being used } \\
\text { as a reinforcement. }\end{array}$ & $\begin{array}{l}\text { Observed that due to the addition of bamboo } \\
\text { mesh the flexibility of walls increased. Also, there } \\
\text { can be a significant cost reduction for walls of up } \\
40 \% \text { and the dead load reduction of up to } 56 \% \text { as } \\
\text { compared to traditional brick walls. }\end{array}$ \\
\hline $\begin{array}{l}\text { P.R. Mali and D. Datta } \\
\text { (2018) }\end{array}$ & $\begin{array}{l}\text { Studied the } \begin{array}{r}\text { experimental } \\
\text { evaluation } \\
\text { reinforced }\end{array} \text { concrete } \text { bamboo } \\
\text { panel. }\end{array}$ & $\begin{array}{l}\text { It was observed that the load carrying and } \\
\text { deformation capacity of concrete slab panel with } \\
\text { newly enhanced bamboo strip improved as } \\
\text { compared to normal PCC and RCC slabs. Also, } \\
\text { the flexural performance has shown significant } \\
\text { improvement. }\end{array}$ \\
\hline
\end{tabular}

From literature, as discussed in the table, it can be apprehended that the application of bamboo as reinforcing material enhances the structural performance of the building components significantly. Out of all the advantages and benefits associated with bamboo, there are also some issues. The first one being the durability. The bamboo strips tend to get weak and splits over a considerable period of time due to absorption of water. The second disadvantage is the decomposition of bamboo because the aqueous concrete is alkaline in nature. The third disadvantage is that the bond strength between bamboo and concrete is not good enough because of the inadequate chemical and mechanical action between the two at the interface (Mali and Datta, 2018). Further, it is affected by the fungus and termite attacks as it has a high content of nutrients. These issues play a significant role on the concrete composite strength due to which the issue of low bond strength of bamboo is a matter of great concern if it is to be used as a sustainable building material. This calls for the standardization of bamboo and application of suitable chemical treatments which is a prime research aspect to combat the problems of bamboo bond strength.

\section{BOND DEVELOPMENT IN CONCRETE}

Bond development between concrete and reinforcing bars ensures the adequate transfer of stress from the reinforcing material to the concrete leading to strain compatibility. This ensures that there is no slippage between the reinforcing bars relative to the surrounding concrete required for their composite behaviour. The bond development mechanism determines the anchorage of reinforcing bars and influences the crack control patterns and section stiffness. The bond behaviour is affected by several factors including concrete nominal cover, reinforcing bar spacing, reinforcing bar size, transverse reinforcement, concrete and steel properties, surface condition of reinforcing bars, position of casting, development and splice length. Further the anchorage length of reinforcing bars depends on the bond strength development between steel and concrete. Different failures occur due to non-provision of adequate anchorage length especially at cantilever supports, lap splices and beamcolumn joint in traditional building design. This highlights the importance of anchorage length which is dependent on sufficient bond strength. When there is proper reliability of end anchorages, there is sufficient bond available due to which the beam can carry applied load even after the unavailability of local bond in other parts of the beam (Subramanian N., Design of RCC Structures).

Conventionally, pull out tests as stipulated by IS 2770 (Part 1) are carried out to determine the bond strength development between the steel bars and concrete. The primary purpose of pull-out tests is to evaluate the interfacial strength between the reinforcing bars and concrete. The arrangement of the conventional pull out test is shown in Figure 4

Pull out test was first introduced in 1938 by Skramtajew, which involved a reinforcement with a spherical end placed in fresh concrete and then measuring the force required to pull it from hardened concrete (Skramtajew, 1938). In 1944, a non-linear relationship between pull out force and 
compressive strength was developed (Carino and Malhotra, 2004). Later, in 1972 the

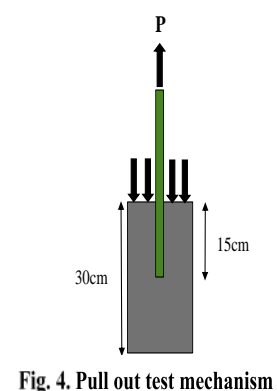

mechanism of concrete failure to determine the relationship between the compressive strength and pull out force was determined by Arni (Arni, 1972). It was concluded that concrete is subjected to a non-uniform, three-dimensional complex state of stress by pull out load. In 1991, Yener and $\mathrm{Li}$ reported that the relationship between concrete strength and pull out force could be attributed to the crushing of concrete (Yener and Li, 1991). In 2000, Ohdaira and Masuzawa concluded that the failure mechanism under pull out loading was based on the progression of microcracking (Ohdaira and Masuzawa, 2000). Pull out load is observed to have a good correlation with the compressive strength of concrete despite the lack of agreement on the failure mechanism. Pull out equipment limits the use only in fresh concrete and cannot be used in existing structures. This led to different instruments investigated in the 1970s (Bungey and Grantham, 2014). Later a post-installation method known as CAPO (Cut and Pull out) test was developed in 1976 having the same geometry as pull out test. Identical correlations between CAPO tests and pull out tests were reported by Petersen in 1997 (Petersen, 1997). Different standard including ASTM C900 (2015) and EN12504 (2005) later included the pull out test and CAPO test as post installed pull out test (Petersen, 1997; Szilagyi and Borosnyoi, 2009).

\section{BAMBOO BOND ISSUES AND TREATMENT PROCESS \& RESULTS}

For bamboo, a natural product with the presence of non- homogeneity such as fiber density variation across thickness affecting its properties, no separate methodology for pull out testing is available. Due to this, effective evaluation of bond strength development is limited under if bamboo fails first in the standard testing mechanism. In 2019, Puri in his experimental investigation observed that the bamboo splints coming out from embedded mortar specimens failed first primarily due to their deterioration during curing. As the standard pull out test mechanism IS 2770 does not provide any guideline to inculcate the specimen degradation, bamboo specimens failed under tension leading to reduced bond strength determination. Further, the guideline does not provide any specifications for incorporating the fiber density variation across the thickness affecting bond strength determination. Hence the bond strength which we get due to friction is not achieved as there is no proper load transfer within the mortar resulting in failure (Puri, 2019). This requires the modification of standard test guidelines.

Further, several issues such as shrinkage, water absorption, species type, etc. affect the bamboo performance in cement composites. Raw bamboo absorbs moisture from the concrete and also from the environment through microcracks in concrete. This results in swelling of bamboo which induces internal local stress degrading the surrounding concrete. Further, shrinkage of bamboo also occurs with a reduction in moisture content leading to voids creation. Due to this continuous cycle of swelling and shrinkage of bamboo, the proper bond cannot be formed between bamboo and concrete and creates a serious limitation to use it as a reinforcement in place of steel (Ghavami, 2005).

Hence to remove these limitations and to achieve high bond strength, various chemical surface treatments are being evaluated on bamboo fibres by different researchers for building different structural components as discussed in Table 2. These chemical coatings make the surface of bamboo impermeable and enhances bond strength development. 
Table 2. Different bamboo surface chemical treatments.

\begin{tabular}{|c|c|c|}
\hline Researcher & Year & Treatments \\
\hline Glenn & 1950 & Asphalt Emulsion \\
\hline Kankam and Perry & 1988 & Bitumen \\
\hline Youssef & 1976 & Varnish \\
\hline Fang and Fey & 1978 & Sulphur \\
\hline Ghavami & 1995 & Negrolin \\
\hline Ghavami & 2005 & $\begin{array}{l}\text { Negrolin } \\
\text { Negrolin with sand } \\
\text { Negrolin with sand and wire } \\
\text { Sikadur } 32 \text { Gel }\end{array}$ \\
\hline Terai and Minami & 2012 & $\begin{array}{l}\text { Synthetic Resin (Spraying/Brush Coating) } \\
\text { Synthetic Rubber (Spraying/Brush Coating) }\end{array}$ \\
\hline Sakaray et al. & 2012 & Waterproof coating \\
\hline Agarwal et al. & 2014 & $\begin{array}{l}\text { Araldite } \\
\text { Araldite with Wire } \\
\text { Tapecrete P 151 } \\
\text { Anti Corr RC } \\
\text { Sikadur } 32 \text { Gel }\end{array}$ \\
\hline Javadian et al. & 2016 & $\begin{array}{l}\text { Water-based epoxy coating } \\
\text { Water-based epoxy coating with fine sand } \\
\text { Water-based epoxy coating with coarse sand } \\
\text { True Grip EP and BP } \\
\text { True Grip EP and BP with coarse sand } \\
\text { Exaphen } \\
\text { Exaphen with coarse sand } \\
\text { Enamel }\end{array}$ \\
\hline Nindyawati et al. & 2016 & Waterproofing paint sprinkled with sand \\
\hline Mulyati et al. & 2016 & Varnish and winding wire \\
\hline Puri et al. & 2017 & Sikadur 32 LP epoxy \\
\hline Dey et al. & 2018 & $\begin{array}{l}\text { Epoxy Coated Sand Rolled Bamboo } \\
\text { Epoxy Coated Coir Rolled Bamboo } \\
\text { Epoxy Coated G.I. Rolled Bamboo } \\
\text { Copper Chrome Boron }\end{array}$ \\
\hline Mali and Datta & 2018 & $\begin{array}{l}\text { Bond Tite Chemical adhesive with Sandblasting } \\
\text { process }\end{array}$ \\
\hline
\end{tabular}

Ghavami in 1995, initially evaluated bamboo reinforcement with different type of coatings (Ghavami, 1995). Further, in 2000 Janssen pointed out the need for bamboo treatment before using it as a reinforcement to increase its life span dramatically. There are different treatment methods available including traditional and chemical methods. Traditional methods are easier and popular such as smoking, air curing, lime washing, seasoning, and soaking. Among the various chemical methods, the most used is the modified Boucherie process (for whole green bamboo culms) and dip diffusion method (for split bamboo culms). To prevent the bamboo from insect and fungal attacks, they should be harvested in the season when their starch content is low (Janssen, 2000).

In 2005, Ghavami reported that after using twocomponent epoxy resin the bonding of bamboo reinforcement increased to up to five times as compared to that of plain bamboo reinforcement (Ghavami, 2005) wherein the bonding shear stress $\tau$ is calculated as shown in equation 1:

$$
\tau=\mathrm{F} /(\mathrm{L} . \mathrm{S})
$$

Where, $\mathrm{F}=$ applied pull load, $\mathrm{S}=$ bamboo perimeter and $\mathrm{L}=$ length of bonded interface.

It was concluded from the test results that the Sikadur 32 Gel treatment gave better values of bond strength. In 2014, Agarwal et al. made a comparison between different adhesives used for improving the bond strength between bamboo and concrete. The various chemical treatments used were Araldite, Araldite with binding wire, Tapecrete P-151, Anti Corr RC, and Sikadur $32 \mathrm{Gel}$. They also reported that Sikadur $32 \mathrm{Gel}$ gave the highest values of bond strength for bamboo and concrete (Agarwal et al., 2014). In 2016, Javadian et al. observed the bond strength between bamboo and concrete by using water-based epoxy coating, TrueGrip EP, TrueGrip BP, and Exaphen coating. These coatings were used with and without sand. They observed that the use of sand marginally improves the bonding between bamboo and concrete due to the enhancement of friction between

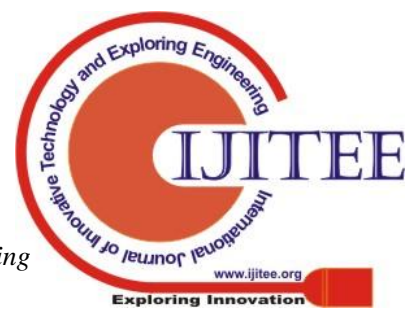


concrete surface and sand particles (Javadian et al., 2016). In 2012, Terai and Minami used a variety of synthetic resin and rubber surface treatments on bamboo for pull out tests. It was reported that the bond stress increased from $0.60 \mathrm{Mpa}$ to $1.34 \mathrm{MPa}$ after the treatment (Terai and Minami, 2012). In 2012, Sakaray et al. carried out the pull out test but with bamboo round culms. It was reported that as the length of embedment increases, the average bond stress decreases. Further, they observed that the decrease of bond stress is more pronounced in case of steel bars. The reason behind this reduction is that the bamboo is anisotropic in nature which has transverse material characteristics and also the larger effects of shear lag (Sakaray et al., 2012). In 2016, Mulyati et al. used two types of bamboo namely Petung and Wulung. Both the bamboos are tested for bond strength by using varnish and winding wire as the treatment. It was observed that Petung bamboo with varnish treatment achieved the highest bond strength of $2.22 \mathrm{MPa}$ (Mulyati and Arman, 2016). In 2016, Nindyawati et al. used Apus bamboo coated with waterproofing paint and sprinkled with sand. The average bond strength achieved was $0.41 \mathrm{MPa}$ (Nindyawati and Umniati, 2016). In 2018, Dey et al. used three types of products as Coir rolled bamboo, G.I. rolled bamboo and Sand rolled bamboo rebar. All these were epoxy coated. It was observed that G.I. rolled bamboo rebar gave the highest bond stress of $9.71 \mathrm{Mpa}$ as compared to that of 5.96 Mpa and 8.46 Mpa for sand rolled and Coir rolled bamboo rebar respectively (Dey and Chetia, 2018). A detailed review of the bond strength achieved using different types of chemical treatments is discussed in Table 3. 
Table 3. Comparison of bamboo bond strength achieved by various researchers with different treatments.

\begin{tabular}{|c|c|c|c|}
\hline Researcher & Year & Treatment/Coating & $\begin{array}{l}\text { Bond Strength } \\
\text { achieved (MPa) }\end{array}$ \\
\hline \multirow{3}{*}{ Ghavami } & \multirow{3}{*}{1995} & Without treatment & 0.52 \\
\hline & & Negrolin + sand & 0.73 \\
\hline & & Negrolin + Sand + Wire & 0.97 \\
\hline \multirow{5}{*}{ Ghavami } & \multirow{5}{*}{2005} & Without treatment & 0.52 \\
\hline & & Negrolin + sand & $\mathbf{0 . 7 3}$ \\
\hline & & Negrolin + Sand + Wire & 0.97 \\
\hline & & Sikadur 32 Gel & 2.75 \\
\hline & & Steel & 3.25 \\
\hline \multirow{7}{*}{ Terai and Minami } & \multirow{7}{*}{2012} & Synthetic resin (Brush Coating) & 1.34 \\
\hline & & $\begin{array}{lllll}\begin{array}{l}\text { Synthetic } \\
\text { @ 25mm }\end{array} & \text { resin } & \text { (Spraying) } & \text { Slot } & \text { processing } \\
\end{array}$ & 1.18 \\
\hline & & Synthetic resin (Spraying) & 1.25 \\
\hline & & Synthetic rubber (Spraying) & 1.18 \\
\hline & & $\begin{array}{l}\text { Synthetic rubber (Spraying) Slot processing } \\
\text { @ 60mm }\end{array}$ & 0.85 \\
\hline & & $\begin{array}{l}\text { Synthetic resin (Brush Coating) Slot processing } \\
\text { @ 40mm }\end{array}$ & 0.60 \\
\hline & & Deformed Bars & 2.43 \\
\hline \multirow{3}{*}{ Sakaray et al. } & \multirow{3}{*}{2012} & Waterproof coating (150mm embedment length) & 1.45-1.95 \\
\hline & & (200mm embedment length) & $1.07-1.25$ \\
\hline & & (260mm embedment length) & $0.95-1.05$ \\
\hline \multirow{6}{*}{ Agarwal et al. } & \multirow{6}{*}{2014} & Plain Bamboo & 0.127 \\
\hline & & Araldite & 0.232 \\
\hline & & Araldite with Wire & 0.539 \\
\hline & & Tapecrete P 151 & 0.315 \\
\hline & & Anti Corr RC & 0.159 \\
\hline & & Sikadur 32 Gel & 0.588 \\
\hline \multirow{3}{*}{ Javadian et al. } & \multirow{3}{*}{2016} & No Coating & 3.61 \\
\hline & & Water Based Epoxy coating & 3.47 \\
\hline & & Water Based Epoxy coating with fine sand & 3.65 \\
\hline
\end{tabular}




\begin{tabular}{|c|c|c|c|}
\hline & & Water Based Epoxy coating with coarse sand & 3.61 \\
\hline & & TrueGrip EP & 3.30 \\
\hline & & TrueGrip EP with coarse sand & 3.45 \\
\hline & & TrueGrip BP & 2.42 \\
\hline & & TrueGrip BP with coarse sand & 2.62 \\
\hline & & Exaphen & 3.36 \\
\hline & & Exaphen with coarse sand & 3.46 \\
\hline & & Enamel & 3.40 \\
\hline Nindyawati et al. & 2016 & Waterproofing paint and sprinkled with sand & 0.41 \\
\hline \multirow{10}{*}{ Mulyati et al. } & \multirow{10}{*}{2016} & Petung bamboo & 0.62 \\
\hline & & Square Petung bamboo with varnish & 2.22 \\
\hline & & Square Petung bamboo with winding wire & 1.90 \\
\hline & & Round Petung bamboo with varnish & 1.70 \\
\hline & & Round Petung bamboo with winding wire & 1.49 \\
\hline & & Wulung bamboo & 0.62 \\
\hline & & Square Wulung bamboo with varnish & 1.33 \\
\hline & & Square Wulung bamboo with winding wire & 0.95 \\
\hline & & Round Wulung bamboo with varnish & 1.12 \\
\hline & & Round Wulung bamboo with winding wire & 0.98 \\
\hline \multirow{2}{*}{ Dey et al. } & \multirow{2}{*}{2018} & Epoxy coated Sand Rolled bamboo bar & 5.96 \\
\hline & & Epoxy coated Coir Rolled bamboo bar & 8.46 \\
\hline
\end{tabular}


As observed from the literature, the bond strength of raw bamboo in concrete is usually improved through surface chemical treatments. Sikadur 32 Gel epoxy coating method and the application of G.I. rolled wires method have been reported to achieve best bond strength results. However, the cost aspects related to these treatments are not well researched upon which could hinder their large scale application. Alternatively, some cheap treatment methods can also be adopted using bituminous material, asphalt paints and tar based paints to make impermeable bamboo (Sharma et al., 2014).

Further, there are very limited studies which determine the effect of concrete or mortar composition on the bond strength development. To increase the bond strength of bamboo, only chemical treatments are not sufficient. In 2006, Jung reported that the dependency of bamboo pull out strength is on various parameters such as mortar composition and strength, loading rate, reinforcement binding. In calculating the bond strength of bamboo composite structures, bond behaviour plays a vital role when it is subjected to different loading conditions (Jung, 2006). In 2019, Puri evaluated and characterized the effect of different factors affecting the cement mortar mix on the bamboo bond strength development in such mixes. It was observed that the bamboo bond strength development is also significantly dependent upon the mortar or concrete mix properties which affect the surface friction development. It was observed that the research is at a very nascent stage on these aspects (Puri, 2019).

\section{CONCLUSION}

In the present study, the application of sustainable building material such as bamboo and the issues affecting its bond strength development in concrete are analyzed. It was observed from the study that with the surface chemical treatments sufficient bamboo bond strength development can be achieved and the issues such as bamboo shrinkage and water absorption can be negated. However, there are no standard guidelines or procedures which stipulates the correct method of treatment. Further, the available guidelines also do not provide any standard testing mechanism incorporating the fiber density variation of bamboo affecting the bond strength determination. Further, the effect of the coefficient of thermal expansion of bamboo affecting its bond behaviour in concrete is not well stipulated upon. This requires further significant research efforts to undermine the potential of bamboo as a sustainable building material. Different treatment methods used in the literature further highlights the great potential of bamboo for the construction industry by achieving significant bond strength compared to steel reinforcement.

\section{REFERENCES}

1. A report on 'Affordable Housing in India - Emerging trends, growth drivers and new opportunities' India Infrastructure Research, Release Date: Oct 18, 2018.
2. Agarwal, A., Nanda, B., \& Maity, D. (2014). Experimental investigation on chemically treated bamboo reinforced concrete beams and columns. Construction and Building Materials, 71, 610-617. http://dx.doi.org/10.1016/j.conbuildmat.2014.09.011

3. Amada, S., \& Untao, S. (2001). Fracture properties of bamboo. Composites Part B: Engineering, 32(5), 451459. https://doi.org/10.1016/S1359-8368(01)00022-1

4. Arni, H. T. (1972). Impact and penetration tests of portland cement concrete. Highway Research Record, No. 378.

5. Brink, F. E., \& Rush, P. J. (1966). Bamboo reinforced concrete construction. US Naval Civil Engineering Laboratory, Port Hueneme, California.

6. Bungey, J. H., \& Grantham, M. G. (2014). Testing of concrete in structures. Crc Press.

7. Carino, N. J., \& Malhotra, V. M. (Eds.). (2004). Handbook on nondestructive testing of concrete. CRC Press.

8. Chow, H. K. (1914). Bamboo as a material for reinforcing concrete (Doctoral dissertation, Massachusetts Institute of Technology).

9. Current World Population. Worldometers (Source: www.worldometers.info/world-population/).

10. Datta, K. (1936). Versuche über die Verwendung von Bambus im Betonbau [Experiments on the use of bamboo in concrete construction]; Datta, K [ramadiswar] (Doctoral dissertation, J. Springer).

11. Dey, A., \& Chetia, N. (2018). Experimental study of Bamboo Reinforced Concrete beams having various frictional properties. Materials Today: Proceedings, 5(1), 436-444. https://doi.org/10.1016/j.matpr.2017.11.103

12. Fang, H. Y., \& Fay, S. M. (1978, August). Mechanism of bamboo-water-concrete interaction. In Proceedings of the International Conference on Materials of Construction for Developing Countries Bangkok (pp. 37-48).

13. Geymayer H.G., \& Cox F.B. (1970). Bamboo reinforced concrete. J Am Concrete Inst 67(51):841-846.

14. Ghavami, K. (1995). Ultimate load behaviour of bamboo-reinforced lightweight concrete beams. Cement and concrete composites, 17(4), 281-288. doi: 10.1016/0958- 9465(95)00018-8

15. Ghavami, K. (2005). Bamboo as reinforcement in structural concrete elements. Cement and concrete composites, 27(6), 637-649. doi:10.1016/j.cemconcomp.2004.06.002

16. Glenn, H. E. (1950). Bamboo reinforcement in portland cement concrete. Engineering Experiment Station.

17. Guinness World Record, Fastest growing plant, United Kingdom Bamboo Plant (Source: http://www.guinnessworldrecords.com/worldrecords/fastest-growing-plant).

18. IS: 2770 (Part 1) - 1967 (Reaffirmed 2007), Methods of testing bonds in Reinforced Concrete, (Part 1) Pull out test.

19. Iyer, S. (2002). Guidelines for building bambooreinforced masonry in earthquake-prone areas in India (Doctoral dissertation, University Of Southern California).

20. Janssen, J. J. A. (2000). Designing and building with bamboo. International Network for Bamboo and Rattan (INBAR). Beijing (No. 20). China: Technical report.

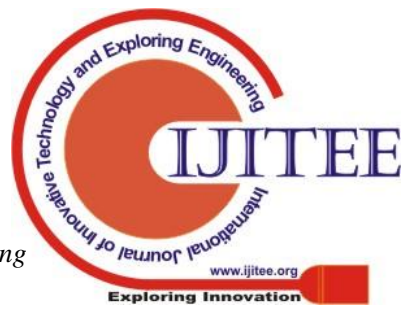


21. Javadian, A., Wielopolski, M., Smith, I. F., \& Hebel, D. E. (2016). Bond-behavior study of newly developed bamboo-composite reinforcement in concrete. Construction and Building Materials, 122, 110-117. https://doi.org/10.1016/j.conbuildmat.2016.06.084

22. Jung, Y. (2006). Investigation of bamboo as reinforcement in concrete. (Master's thesis, The University of Texas at Arlington).

23. Kankam, J. A., BEN, G. M., \& Perry, S. H. (1986). Bamboo Reinforced Concrete Two-way slabs subjected to Concentrated Loading.

24. Kankam, J. K., Ben-George, M., \& Perry, S. H. (1988) Bamboo-reinforced concrete beams subjected to thirdpoint loading. Structural Journal, 85(1), 61-67.

25. Khare, L. (2007). Performance evaluation of bamboo reinforced concrete beams. http://hdl.handle.net/10106/210

26. Mali, P. R., \& Datta, D. (2018). Experimental evaluation of bamboo reinforced concrete slab panels. Construction and Building Materials, 188, 1092-1100. https://doi.org/10.1016/j.conbuildmat.2018.08.162

27. Mansur, M. A., \& Aziz, M. A. (1983). Study of bamboomesh reinforced cement composites. International Journal of Cement Composites and lightweight concrete, 5(3), 165-171.

28. McClure (1953). Bamboo as a building material. Department of Housing and Rural Development USA, (pp. 1-52).

29. Mulyati, \& Arman (2016). The Evaluation of Bond Strength of Bamboo Reinforcement in Concrete. International Conference on Technology, Innovation, and Society (ICTIS). https://eproceeding.itp.ac.id/

30. National Cement Consumption CAGR 2017-2021, Cemex Day, 2017 (Source: CEMEX CemWeek).

31. Nindyawati, \& Umniati, B. S. (2016). Bond Strength of Bamboo Reinforcement in Light Weight Concrete. Journal of Civil Engineering and Architecture 10, 417 420. doi: 10.17265/1934-7359/2016.04.003.

32. Ohdaira, E., \& Masuzawa, N. (2000). Water content and its effect on ultrasound propagation in concrete-the possibility of NDE. Ultrasonics, 38(1-8), 546-552.

33. Petersen, C. G. (1997, April). LOK-TEST and CAPOTEST pullout testing, twenty years' experience. In Proceedings of the International Conference on Nondestructive Testing in Civil Engineering (pp. 77-96). British Institute of Nondestructive Testing.

34. Puri, V., Chakrabortty, P., Anand, S., \& Majumdar, S. (2017). Bamboo reinforced prefabricated wall panels for low cost housing. Journal of Building Engineering, 9, 5259. http://dx.doi.org/10.1016/j.jobe.2016.11.010

35. Puri, V. (2019). Development of prefabricated bamboo reinforced fly ash replaced green mortar wall panels. (Doctoral dissertation, Indian Institute of Technology, Patna, India).

36. Sakaray, H., Togati, N. V. K., \& Reddy, I. R. (2012). Investigation on properties of bamboo as reinforcing material in concrete. International Journal of Engineering Research and Application, 2, 077-083.

37. Schröder S., "Amazing Facts about Bamboo", Bamboo Import Europe, (April, 2016) (Source: https://www.bambooimport.com/en/blog/facts-aboutbamboo).

38. Sharma, B., Gatoo, A., Bock, M., Mulligan, H., \& Ramage, M. (2014). Engineered bamboo: state of the art. Proceedings of the Institution of Civil EngineersConstruction Materials, 168(2), 57-67. https://doi.org/10.1680/coma.14.00020

39. Skramtajew, B. G. (1938, January). Determining concrete strength for control of concrete in structures. In Journal Proceedings (Vol. 34, No. 1, pp. 285-304).
40. Subramanian N., Design of Reinforced Concrete Structures, Oxford University Press, ISBN 13:978-0-19808694-9, (pp. 262-264).

41. Steel Demand, Finished Steel, Worldsteel Association (Source: worldsteel.org)

42. Szilágyi, K., \& Borosnyói, A. (2009). Years of experience with the Schmidt rebound hammer. Concrete Structures, 10, 46-56.

43. Terai, M., \& Minami, K. (2011). Fracture behavior and mechanical properties of bamboo reinforced concrete members. Procedia Engineering, 10, 2967-2972. doi:10.1016/j.proeng.2011.04.492

44. Terai, M., \& Minami, K. (2012). Research and development on bamboo reinforced concrete structure. 15 WCEE.

45. Xiao, Y., Yang, R. Z., \& Shan, B. (2013). Production, environmental impact and mechanical properties of glubam. Construction and Building Materials, 44, 765773. https://doi.org/10.1016/j.conbuildmat.2013.03.087

46. Yao, W., \& Li, Z. (2003). Flexural behavior of bamboofiber-reinforced mortar laminates. Cement and Concrete Research, 33(1), 15-19. https://doi.org/10.1016/S00088846(02)00909-2

47. Yener, M., \& Li, G. C. (1991). Progressive finite element fracture analysis of pullout concrete. Journal of Structural Engineering, 117(8), 2351-2371.

48. Youssef, M. A. R. (1976). Bamboo as a substitute for steel reinforcement in structural concrete. New Horizons in Construction Materials, 1, 525-554.

\section{AUTHORS PROFILE}

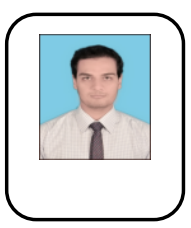

Abhishek Dixit - He did his Masters in Structura Engineering from Amity University, Noida. He had a good academic experience as an Assistant Professor in various colleges. He has 2 papers published in SCOPUS Indexed Journal and 1 paper presented at an International Conference. His research area is Sustainable Infrastructure, recycled materials, Industrial by-products and Bamboo reinforcement in concrete.

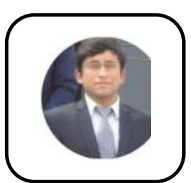

Dr. Vishal Puri - He is currently working as an Assistant Professor in Amity University, Noida. He has completed his doctorate from IIT, Patna. He has several research papers published in Scopus Indexed Journal, Elsevier and Springer. Apart from that he has presented in various National and International conferences. 